\title{
Crystal-Chemical and Technological Features of the KMA Natural Magnetites
}

\author{
T. Gzogyan ${ }^{(凶)}$ and S. Gzogyan \\ Belgorod National Research University, Belgorod, Russia \\ mehanobrl@yandex.ru
}

\begin{abstract}
The results of researches of crystal-chemical features of magnetites obtained from the KMA ferruginous quartzites deposits are presented. It is shown that all magnetites are represented by cation-scarce mineral differences. The correlation dependences between the technological indexes (yield, extraction) and the magnetite concentration in quartzites are established.
\end{abstract}

Keywords: Crystal-chemical features $\cdot$ Ferruginous quartzites $\cdot$ Magnetite $\cdot$ Maghemite $\cdot$ Mossbauer spectra $\cdot$ Magnetic properties $\cdot$ Defectiveness

\section{Introduction}

The most important geochemical feature of iron is the presence of several oxidation degrees. By crystal-chemical properties of the $\mathrm{Fe}^{2+}$ ion is close to the $\mathrm{Mg}^{2+}$ and $\mathrm{Ca}^{2+}$ ions and to the other main elements. Due to crystal-chemical similarity Fe replaces $\mathrm{Mg}$ and partially $\mathrm{Ca}$ in many silicates. In quartzites, the main ore mineral is magnetite, the crystal-chemical structure characteristics of which determine the technological properties of quartzites, according to which quartzites are characterized by high variability of composition and properties, and the results of enrichment depend on their material composition. It is worth noting the diversity of mineral composition, texture and structural features of ores and, as a consequence, a wide range of physical, mechanical and technological properties (Gsogyan 2010).

\section{Methods and Approaches}

In this work the crystal-chemical features of the main ore minerals of unoxidized and oxidized quartzite KMA deposits are investigated using modern research methods (nuclear gamma-resonance spectroscopy (Mossbauer effect), X-ray analysis and X-ray fluorescence). Measurements of the dependence of magnetization on the applied magnetic field and saturation magnetization by the vibration method are carried out.

Magnetite is a typomorphic mineral composition and properties of which depends on the conditions of formation and has got a structural spinel. This is the ohFd $3 \mathrm{~m}$ space group, where cations occupy 16 octahedral (B) and 8 tetrahedral (A) positions. Therefore, for ideal crystals of $\mathrm{Fe}_{1}^{3+}\left[\mathrm{Fe}_{1}^{3+} \mathrm{F}_{1}^{2+}\right] \mathrm{O}_{4}$ the reversed spinel, the ratio of the intensities of the leftmost lines of the mossbauer absorption spectra, taking into account 
the difference in the probabilities of the effect for the octahedral and tetrahedral sublattices, should be slightly less than two.

\section{Results and Discussion}

The characteristic lines of the obtained Mössbauer absorption spectra of quartzites represent the superposition of a series of six-peak spectra. The ratio of the intensities corresponding to half of the ions in the A and B positions is practically not satisfied, despite the fact that the selected sample is closest to the monomineral difference. In addition, there is also a slight broadening of the leftmost and rightmost lines of the total absorption.

Mossbauer spectra indicate that the intensity ratio $1: 2$ is not satisfied. Violation of this ratio may be due either to an isomorphic substitution of iron ions in the B-position of $\mathrm{Fe}_{1}^{3+}\left[\mathrm{Fe}_{5 / 3-2 / 3 \mathrm{X}}^{3+} \mathrm{F}_{\mathrm{X}-\mathrm{Y}}^{2+} \mathrm{Me}_{\mathrm{y} \square 1 / 3-1 / 3 \mathrm{X}}^{2+}\right] \mathrm{O}_{4}$ or to the phenomenon of non-stoichiometry and the presence of $\mathrm{Fe}_{1}{ }^{2+}$ vacancies in the same position $\mathrm{Fe}_{1}^{3+}\left[\mathrm{Fe}_{5 / 3-2 / 3 \mathrm{X}}^{3+} \mathrm{F}_{\mathrm{X}-\mathrm{Y}}^{2+} \mathrm{Me}_{\mathrm{y} \square 1 / 3-1 / 3 \mathrm{X}}^{2+}\right] \mathrm{O}_{4}$. Obviously, at $\mathrm{x}=1$, this is the stoichiometric magnetite $\mathrm{Fe}_{1}^{3+}\left[\mathrm{Fe}_{1}^{3+} \mathrm{F}_{1}^{2+}\right] \mathrm{O}_{4}$, and at $\mathrm{x}=0-\gamma-\mathrm{Fe}_{2} \mathrm{O}_{3}\left(\mathrm{Fe}_{1}^{3+}\left[\mathrm{Fe}_{5 / 3 \square 2 / 3 \mathrm{X}}^{3+}\right] \mathrm{O}_{4}\right)$. The appearance of isomorphically replacing ions in the octahedral position of the magnetite spinel structure leads to a partial removal of electron exchange in position $\mathrm{B}$ between $\mathrm{Fe}^{2+}$ and $\mathrm{Fe}^{3+}$ and, as a result, to a change in the ratio of the intensities of the lines corresponding to iron ions in positions $\mathrm{A}$ and $\mathrm{B}$ with simultaneous broadening of not only the extreme right groups of lines, but also the entire set of lines of the total resonance absorption spectrum (broadening is especially pronounced with an increase in the concentration of isomorphically substituting ions). The appearance of a cationic vacancy in position $\mathrm{B}$ of the spinel structure does not lead to experimentally observed broadening but only to a redistribution of the intensities of the lines corresponding to $\mathrm{Fe}^{3+}$ and $\left[\mathrm{Fe}^{3+}, \mathrm{Fe}^{2+}\right]$ in positions $\mathrm{A}$ and $\mathrm{B}$ due to increasing in the contribution of $\mathrm{Fe}^{3+}$ which does not participate in electronic exchange $\mathrm{Fe}^{2+}$ with position $\mathrm{B}$ due to vacancies. But in both cases the integral intensity remains constant. However, the presence of a cationic vacancy in the octahedral position in the spinel structure significantly affects the technological properties. The combination of experimental data obtained allows us to write the crystal-chemical formula of magnetites in the form $\mathrm{Fe}_{1}^{3+}\left[\mathrm{Fe}_{5 / 3-2 / 3 \mathrm{X}}^{3+} \mathrm{Fe}_{\mathrm{x} \square 1 / 3-1 / 3 \mathrm{X}}^{2+}\right] \mathrm{O}_{4}$, where $\square-$ is a cation vacancy (in the structure of magnetite as isomorphic substituting ions can be $\mathrm{Mg}^{+2}, \mathrm{Mn}^{+2}, \mathrm{Ni}^{+2}, \mathrm{Ti}^{+2}$, etc.), and $\mathrm{x}-$ is non-stoichiometric (the defectiveness is the $\mathrm{Fe}^{2+}$ deficiency widely varying in area of deposits). At $\mathrm{x}=0$ we have a six-peak absorption spectrum corresponding to maghemite. The condition of electro-neutrality is observed due to the formation of defects that is, electron holes. The relationship between $\mathrm{Fe}^{3+}$ and $\left[\mathrm{Fe}^{3+}, \mathrm{Fe}^{2+}\right]$ determines the behavior of such magnetites in magnetic fields.

In addition, martite lines are present on the Mossbauer spectra of magnetites and this indicates that the crystal lattice of magnetites is coherently connected with the lattice of the "parent" magnetite. The presence of a coherently coupled 
$\mathrm{Fe}_{1}^{0}\left[\mathrm{Fe}_{5 / 3 \square 1 / 3}^{3+}\right] \mathrm{O}_{4}$ structure significantly affects the degree of its extraction during the enrichment. Traces of hematite and various non-metallic particles are present with magnetite.

Thus, magnetite is a very sensitive indicator of the conditions of deposits formation and its "life", started in nature, is manifested and sometimes significantly in the kinetics of technology, because rapid processes intensively destroy its information structure and slowly transfer it to the products resulting from processing (Gsogyan 2010).

Features of heterogeneity of the composition and properties of magnetite affect the variability of its oxidation degree in the course of crushing process and, as a result, the technological indicators of enrichment (Gsogyan 2010). Quantitative XRF of quartzites revealed the presence in them along with magnetite, hematite and maghemite; moreover, the presence of maghemite is the characteristic of all mineral types of quartzite. XRF showed that the highest content of maghemite $(\sim 11 \%)$ is the characteristic of magnetite quartzite, somewhat lower $(\sim 8 \%)$ is observed in semi-oxidized and the lowest $(\sim 4.5 \%)$ in oxidized.

Morphological series observed in nature in ferruginous quartzites: $\mathrm{Fe}_{4} \mathrm{O}_{4}$ (wustite) $\rightarrow \mathrm{Fe}^{2+} \mathrm{Fe}_{2}{ }^{3+} \mathrm{O}_{4} \quad$ (magnetite) $\rightarrow \gamma \mathrm{Fe}_{2} \mathrm{O}_{3} \quad$ (maghemite) $\rightarrow \alpha \mathrm{Fe}_{2} \mathrm{O}_{3} \quad$ (hematite) $\rightarrow \mathrm{Fe}_{2} \mathrm{O}_{3} \cdot \mathrm{H}_{2} \mathrm{O} \quad$ (goethite) $\rightarrow \gamma \mathrm{FeO}(\mathrm{OH}) \quad$ (lepidocrocite) $\rightarrow \mathrm{Fe}_{2} \mathrm{O}_{3} \cdot \mathrm{xH}_{2} \mathrm{O}$ (limonite /martite) emphasizes the complex relationships between their structures. With the transition from one structural type to another, some features of the original type are inherited. The edge of the unit cell, depending on the composition of the oxidation of wustite to magnetite and maghemite consistently decreases with the number of $\mathrm{Fe}^{2+}$ cations. Linear dependence of the lattice parameter on the composition emphasizes the similarity between the structures of these compounds. Reducing edges of the unit cell of magnetite in the transition to maghemite caused by the replacement of $\mathrm{Fe}^{2+}$ with an ionic radius of $0,80 \AA$ on $\mathrm{Fe}^{3+}$ with an ionic radius of $0,67 \AA$ with simultaneous removal of one third of the $\mathrm{Fe}^{2+}$ ions from the structure of magnetite. The magnetites associated with the incomplete processes of martitization are highly heterogeneous, which is associated with the manifestation of morphotropic transformations in the series indicated above, the content of $\mathrm{Fe}$ in which falls from $72.4 \%$ (magnetite) to $62.0 \%$ (limonite).

The average edge size of the unit cell varies from $8.371 \AA$ (Lebedinsky) to $8.395 \AA$ (Mikhailovsky) and this is somewhat less than that of a magnetite of stoichiometric composition (8.396 $\AA$ ). The evaluation of magnetite deformations allows us to conclude that a change in the main interplanar distances of magnetite samples is more characteristic of Lebedinsky and Prioskolsky.

Microprobe analysis revealed iron deficiency in magnetite grains of various generations, the content of which varies from $66.89 \%$ (Mikhailovsky) to $72.3 \%$ (Stoilensky).

Thermomagnetic analysis in almost all magnetites at $\mathrm{T}=340-350{ }^{\circ} \mathrm{C}$ shows a weak exothermic effect corresponding to maghemite and its presence is confirmed by electron diffraction patterns, which indicate the absence of periodicity in the arrangement of some reflexes and the presence of defects and dislocations in the magnetite lattice (Fig. 1). 


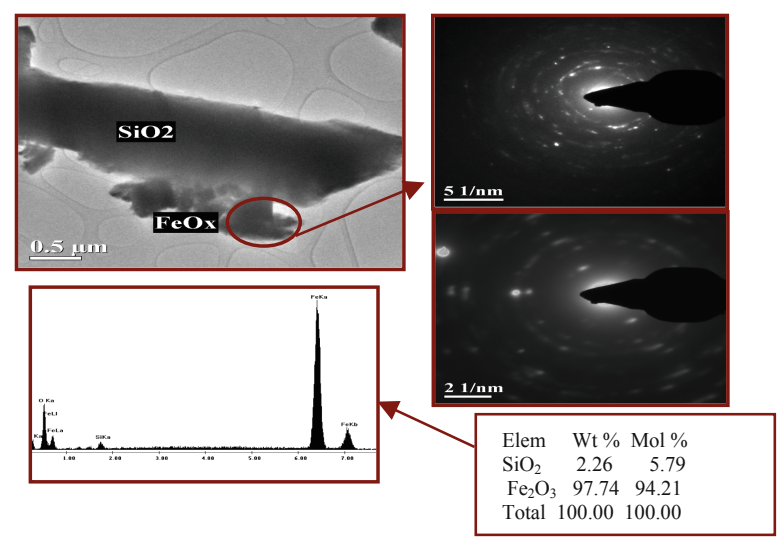

Fig. 1. The electron phase, taken from the magnetite particles at different angles of orientation of the device

Maghemite is marked from 11\% (Mikhailovsky and Prioskolsky) to 6\% (Korobkovsky). The data of high-temperature magnetometry confirm the lack of $\mathrm{Fe}^{+2}$ in the KMA magnetites and their difference from stoichiometric: the Curie point for magnetite averaged $571.8 \AA$ (Stoilensky) to $578.3 \AA$ (Prioskolsky). The change in the ratio of $\mathrm{Fe}^{3+}$ and $\mathrm{Fe}^{2+}$ causes the inextensive magnetic properties which are one of the most important factors affecting the enrichment. These studies suggest that, due to the lack of a sufficient amount of isomorphic impurities, we are dealing with alternative behavior in the two-phase system of $\mathrm{Fe}_{2} \mathrm{O}_{3} \div \mathrm{Fe}_{3} \mathrm{O}_{4}$, that is, the formation of metastable transitional phases with a structure closer to the matrix than the equilibrium phase. This is confirmed by the results of determining the concentrations of isomorphically substituting impurities of $\mathrm{Mg}^{2+}, \mathrm{Mn}^{2+}, \mathrm{Ti}^{2+}$ and $\mathrm{Ni}^{2+}$, which did not exceed $0.2 \% \mathrm{NiO}$; $0.25 \% \mathrm{MnO}_{2}$ and $0.4 \% \mathrm{MgO}$.

All Mossbauer absorption spectra contain maghemite lines. Consequently, the formation of solid solutions of $\mathrm{FeO}: \mathrm{Fe}_{2} \mathrm{O}_{3}$ coherently coupled with $\gamma-\mathrm{Fe}_{2} \mathrm{O}_{3}$ and semicoherently with $\mathrm{Fe}_{2} \mathrm{O}_{3}$ is strictly observed in deposits. This led to the widespread development of quartzites heterogeneity in their composition and properties. The coherent phases formed in this way can be clusters of dissolved atoms in the lattice of the parent material that is often observed. The presence of "non-stoichiometric" cationdeficient differences of magnetites led to the need to find the value that determines their defectiveness. The crystal-chemical formula of such magnetites is: $\mathrm{Fe}_{1}^{3+}\left[\mathrm{Fe}_{5 / 3-2 / 3 \mathrm{X}}^{3+} \mathrm{Fe}_{\mathrm{x}}^{2+} \mathrm{Fe}_{1 / 3-1 / 3 \mathrm{X}}^{2+}\right] \mathrm{O}_{4}$ where $\mathrm{x}$ is defectiveness $\left(\mathrm{Fe}^{2+}\right.$ deficiency in the octahedral position of the spinel structure) (for $\mathrm{x}=1$ is ideal magnetite $\mathrm{Fe}^{3+}\left[\mathrm{Fe}_{1}^{3+} \mathrm{Fe}^{2+}\right] \mathrm{O}_{4}$ (content of $72.4 \%$ ), and at $\mathrm{x} \rightarrow 0$ a complete transition up to $\gamma-$ $\mathrm{Fe}_{2} \mathrm{O}_{3}$ (crystallographic symmetry) $\mathrm{Fe}_{1}^{3+}\left[\mathrm{Fe}_{5 / 3}^{3+} \mathrm{Fe}_{1 / 3}^{2+}\right] \mathrm{O}_{4}$ when a part of iron ions is recharged to the state of $\mathrm{Fe}^{3+}$ and the iron content drops to $69.9 \%$ ).

The dependence of the magnetic properties on the composition and crystalchemical features of magnetites is performed by the vibration method in a uniform magnetic field $\mathrm{H}$ up to $71.62 \mathrm{kA} / \mathrm{m}$ in the temperature range from 20 to $800{ }^{\circ} \mathrm{C}$. The 
obtained dependence of the specific saturation magnetization has an inflection point which apparently is associated with the influence of a sufficiently large weight fraction of $\mathrm{Fe}_{1}^{3+}\left[\mathrm{Fe}_{5 / 3}^{3+} \mathrm{Fe}_{1 / 3}^{2+}\right] \mathrm{O}_{4}$ The unevenness of magnetic properties is due to the change in the ratio of $\mathrm{Fe}^{3+}$ and $\mathrm{Fe}^{2+}$. Specific magnetic susceptibility indicates a different petrographic composition of ores and the size of magnetite impregnation and their significant heterogeneity which is a consequence of their genesis and is expressed in the difference in their technological properties. The saturation magnetization is a multiparameter function for ferruginous quartzites.

In this regard, the dependences of technological indicators of enrichment were obtained as a function of the reduced value $\left(\sigma_{\mathrm{s}} / \sigma_{\mathrm{s}}^{\mathrm{id}}\right)$, where $\sigma_{\mathrm{s}}$ are the obtained values of the specific magnetization of this sample; $\sigma_{\mathrm{s}}^{\text {id }}$ is the specific magnetization of the isolated magnetite fraction $\left(\mathrm{Fe}_{\text {tot }}=72.2 \%, \mathrm{SiO}_{2}\right.$ less than $\left.0.2 \%\right)$.

\section{Conclusions}

- magnetites from ferruginous quartzite deposits of the KMA are represented by cation-deficient mineral differences with a wide variation of the magnitude of defects $(\mathrm{x})$ in the area of occurrence;

- the presence of coherently bound $\gamma-\mathrm{Fe}_{2} \mathrm{O}_{3}$ and semi-coherently bound $\alpha-\mathrm{Fe}_{2} \mathrm{O}_{3}$ is determined depending on the degree of oxidation which undergoes spinodal and intracrystalline decomposition up to hematite;

- technological indicators of enrichment depends on the crystal-chemical and magnetic properties of quartzites. These allow to find optimal conditions for concentrates obtaining, i.e. implement the "geological" management of the production.

\section{Reference}

Gzogyan TN (2010) To the question of the heterogeneity of the KMA magnetite deposits. Min Inf-Anal Bull (5):256-259

Open Access This chapter is licensed under the terms of the Creative Commons Attribution 4.0 International License (http://creativecommons.org/licenses/by/4.0/), which permits use, sharing, adaptation, distribution and reproduction in any medium or format, as long as you give appropriate credit to the original author(s) and the source, provide a link to the Creative Commons license and indicate if changes were made.

The images or other third party material in this chapter are included in the chapter's Creative Commons license, unless indicated otherwise in a credit line to the material. If material is not included in the chapter's Creative Commons license and your intended use is not permitted by statutory regulation or exceeds the permitted use, you will need to obtain permission directly from the copyright holder.

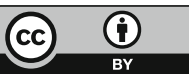

